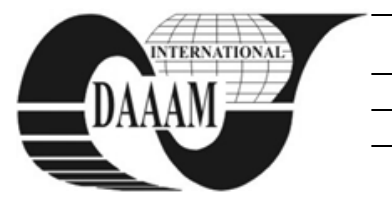

Annals of DAAAM for 2011 \& Proceedings of the 22nd International DAAAM Symposium, Volume 22, No. 1, ISSN 1726-9679 ISBN 978-3-901509-83-4, Editor B. Katalinic, Published by DAAAM International, Vienna, Austria, EU, 2011 Make Harmony between Technology and Nature, and Your Mind will Fly Free as a Bird Annals \& Proceedings of DAAAM International 2011

\title{
STUDY OF THE DURABILITY OF MATERIALS USED IN TURNOUT CROSSINGS
}

\author{
BRUTANS, V[aldis] \& TORIMS, T[oms]
}

\begin{abstract}
Studies of the durability of heavily loaded crossings in Latvian Railway provide information about the use of innovative materials and the impact of geometric improvements on their design. An empiric connection has been found on the basis of experimental results which enables making forecasts as to the service life of crossings. The experience thus acquired enables railway infrastructure to select crossings of the proper design more efficiently, thereby reducing life-cycle costs.

Key words: railway, crossings, design, maintenance, durability, materials, wear
\end{abstract}

\section{INTRODUCTION}

A crossing is one of the most heavily loaded units of the turnouts. Fixed crossings are subjected not only to the rolling load but also to a dynamic transition load at the place of interruption in the running surface. In this transition zone, the wheel either rolls down from the crossing vee onto the wing rail or vice versa, depending on the direction of movement (against or along the crossing vee). During the transition, the contact surface of the wheel and the running surface with the wing rail and the crossing vee changes. Because of this, under the influence of various other circumstances (wear of the wheel, uneven wear of the crossing vee and of the wing rail, condition of the rail track surface structure, geometrical indicators of the switch), the transition zone of the crossings may be subjected to heavy overloads, resulting in the appearance of cavities, splitting into layers, material flow in the running surface. (Skarstins et. al. 2001)

\section{TASK}

To achieve the extension of the service life of crossings by introducing minimal changes to the design and materials. This means preserving the principal structure in its current state. Freedom of choice is left in the selection of materials and the improvement of design elements.

\section{SOLUTION}

A cross-section diagram of the transition zone is provided in Figure 1. The figure shows the wheel flange as it rolls along the groove, while the outer edge of the wheel remains in contact with the running surface of the wing rail.

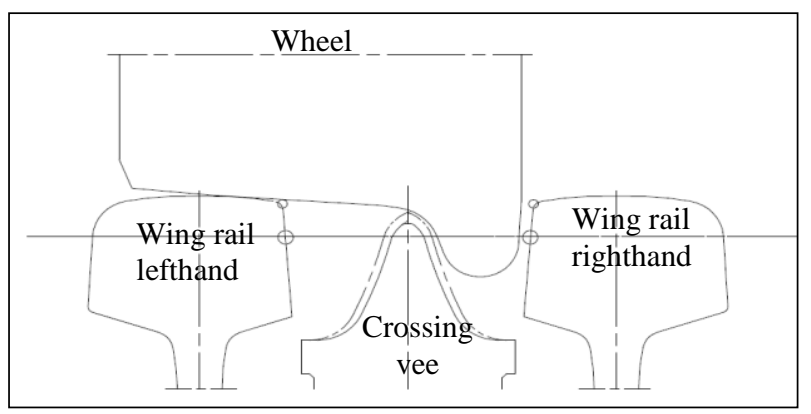

Fig. 1. Cross-section of the transition zone
When the lowering in the crossing vee runs out, the wheel gradually comes into contact with the crossing vee. The wheel simultaneously forms contact with both the wing rail and the crossing vee for a small distance, thus mutually sharing the summary contact surface. As the wheel rolls on, the contact with the wing rail is lost and the wheel now rolls only along the crossing vee. Here the design must provide for the formation of a contact between wear-prone surfaces, and the condition of the wheel pair is difficult to predict. Both new and heavily worn-out wheels may be used in the same set of railway cars. The contact area of the transition zone is heavily affected by wheel geometry. A way must be found how to enlarge the contact area in the crossings transition zone. (Brutans et. al. 2010)

Two directions have been identified in which to search for possible improvements:

- Geometric improvements

- Changes to the materials used

Geometrical improvements. The transition zone is directly influenced by the cross-section and the longitudinal profile of the wing rail and of the crossing vee. First what that can be done is to reduce the size of the groove (from $46 \mathrm{~mm}$ to $45 \mathrm{~mm}$ ). The reduction of the groove results in a bigger load being exerted on the check rail which is designed to move the wheel truck away from the end of the crossing vee. There also exists the risk of wheels hitting the crossing vee frontally. Therefore, in order to prevent the frontal battering of the vee, narrowing of the tongue piece from the nominal $12 \mathrm{~mm}$ (standard solution) to $8 \mathrm{~mm}$ is made as part of the 'safe' lowering solution (where no contact occurs between a pair of wheels and the crossing vee theoretically) (see Figure 2).

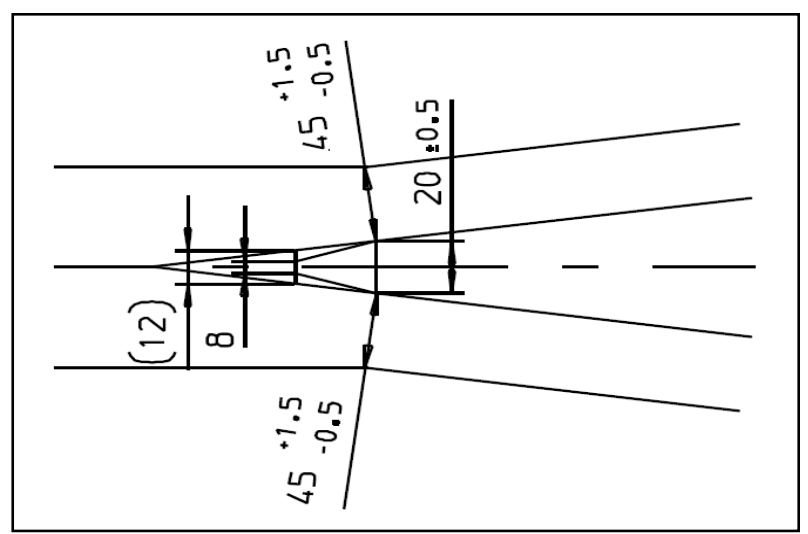

Fig. $2.45 \mathrm{~mm}$ groove and $8 \mathrm{~mm}$ crossing vee

The second place for improvement is the wing rail. The curvature radius of the treated section of a standard-design wing rail is $10 \mathrm{~mm}$. An additional $5 \mathrm{~mm}$ are obtained for increasing the contact area by reducing the radius by half (see Figure 3 ). In this case, a smaller curvature radius is not desirable as this can result in problems with the rail surface flow, untimely grinding, leading to rail failure, i.e., formation of break-offs.

Changes to materials. The choice of used materials is determined by their availability and whether they are considered a 
novelty in the world market. In order to verify the efficiency of geometrical improvements it is expedient to use standard materials (according to the specifications of Latvian Railway) in the production of one type of crossings: crossings vee VARIO W720 and wing rails $60 \mathrm{E} 1 \mathrm{R} 350 \mathrm{HT}$.

The most common material used for the production of crossing vee not only in Western Europe but also in empirical the rest of the world is the so-called MN13 manganese alloy.

In Germany, crossings, especially the crossings for use in heavily loaded railway sections, have been produced from bainitic steel for a very long time. This material is little known in Eastern Europe; however, considering good references from the German railway sector, BAINIT has been selected as the third material to be used in the test crossing vees. (Guggenberger et. al. 2009)

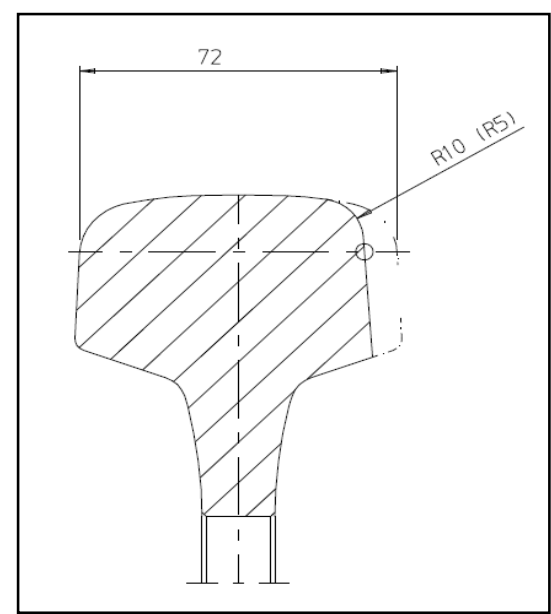

Fig. 3. Wing rail (60E1) cross-section

Testing was concurrently conducted on a new type of wing rails and closure rails of grade R370CrHT. This rail material was used in the design of bainit and Mn13 crossings.

For the purposes of this study, 3 types of crossings were built into the rail tracks of Latvian railway, three from each type, in three different stations. Data were collected about the condition of the crossings (wear pattern, frequency of grinding, and various other repairs) over a period of two years, at the measurement interval of 3 months.

\section{RESULTS}

Studies shows that the smallest extent of wear at the end of the experiment is found in crossings of the Bainit type. The Mn13 crossing vee shows an uneven degree of wear among heavily loaded zones and zones under normal load, while crossing vees of the Bainit and Vario types show a uniform linear wear.

As no running surface defects were found in VARIO crossings during the experiment, one can assume that the service life of these crossings is directly dependent on normal wear.

Based on the data obtained in the experiment, see below the crossing vee lowering function (1) which depends on the service time, assuming that the grinding intensity is once a month.

$$
d=0.0048 L^{2}-0.0514 L+2.875+0.015 T
$$

Where,

$\mathrm{d}$ - summary crossing vee lowering, $\mathrm{mm}$

$\mathrm{L}$ - service time, in months

$\mathrm{T}$ - cargo tons passed over, $\mathrm{t}$

The calculations show that in case of normal wear, the crossing vee reaches the maximum degree of wear after 37 months (appr. 3 years)

By evaluating all the data on the wear of wing rails obtained during the study one may conclude that grade $\mathrm{R} 370 \mathrm{CrHT}$ rails are the most wear-resistant ones, as testified by Figure 4 . The wear progress is very similar for both rail types, although, as a tendency, the wear of grade $\mathrm{R} 370 \mathrm{CrHT}$ rails is slightly lower.

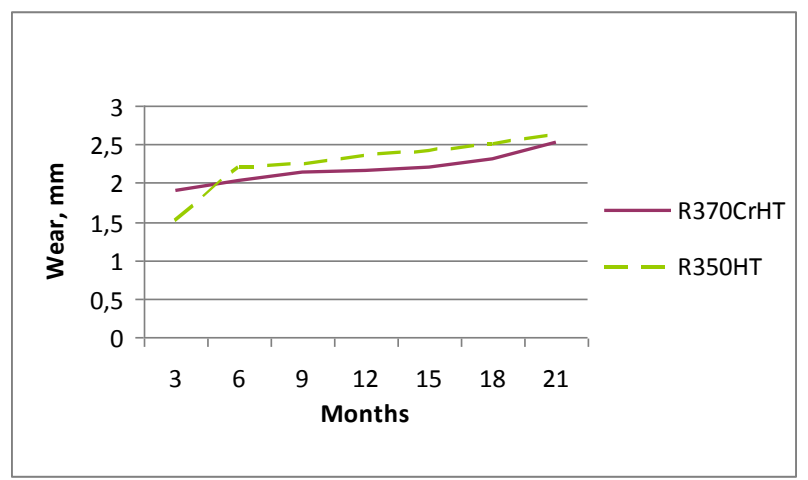

Fig 4. Characteristic curves of wing rails

\section{CONCLUSION}

The data obtained in the experiments lead to the conclusion that VARIO crossing vees are the most resistant ones against wear and running surface defects in terms of materials. Based on the calculations used in Formula (1), one may conclude that the durability of the crossings is higher, i.e., up to 3 years, which is the warranty term until the first repair welding is required. These empirical premises may also be used to calculate the durability of other types of crossings and to make forecasts concerning the required scope of repairs.

The implemented design improvements have justified themselves. This is proved by good service results of VARIO crossings.

The principal direction in which work should be done in order to improve the wear resistance of crossings is improvement of the design. Changes can also be made to the existing design in order to obtain a positive effect with regard to improving the service life of crossings. Another direction to pursue is to use turnouts of a larger radius in which the transition zone in the crossings section is longer, which compensates for the shortcomings in the wheel geometry.

Rail material of grade R370 CrHT shows a good potential in terms of its wear resistance but, since its production costs are higher than those of grade R350HT, and since significant running surface defects were discovered in the course of the experiment, rails of grade $\mathrm{R} 350 \mathrm{HT}$ are found to be a safer material for wing rails.

\section{REFERENCES}

Brutans, V. (2011), Impact of manufacturing technology of durability of Turnout crossings, Available from: https://ndr.rtu.lv/view.php?id=2389\&lan=lv Accessed: 2011 06-09

Brurtans, V. (2011). Sliežu ceļu pārmiju detaļu ilgizturības pétījumi (Studies of durabiltity of Railroad Turnout parts), $52^{\text {nd }}$ RTU Technical conference 2011, RTU, Riga

Brurtans, V. (2010). Pārmiju krusteņu ilgizturības pētījumi (Studies of durabiltity of Turnout crossings), 51 ${ }^{\text {st }}$ RTU Technical conference, 2010, RTU, Riga

Guggenberger, E. (2009), Technical Documentation, VAE, Zeltweg, Austria

Skarstins, A. (2001). Apkopes un uzturēšanas ieteikumi parastiem pārmiju krusteñiem un pretsliedèm (Maintenance recommendations for single crossings and guard rails), VAE, Riga, Latvia 